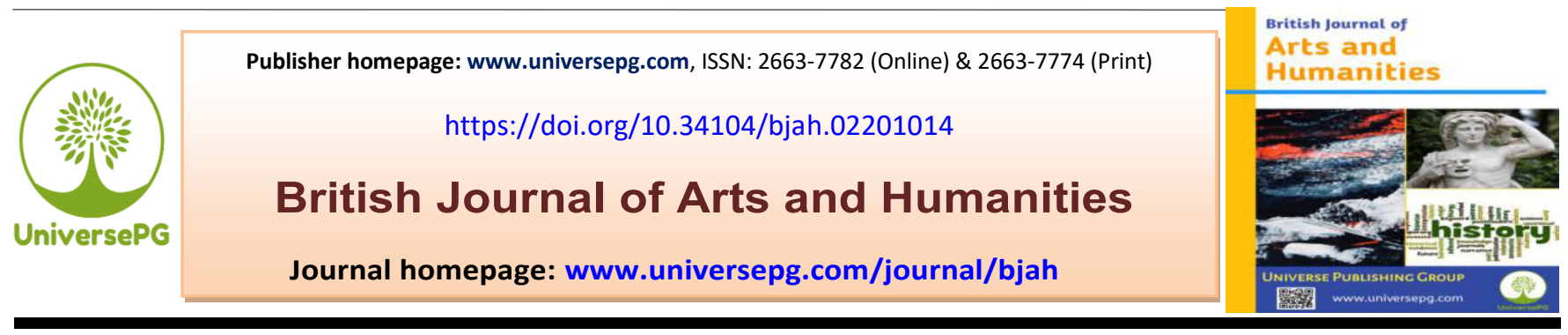

\title{
Rainfall and Landslide Susceptibility in Hakha Environ in Northern Chin State, Myanmar
}

\author{
May Thu Naing ${ }^{1 *}$, Mar Mar Aye ${ }^{2}$, and Kyaw Lwin $\mathrm{Oo}^{3}$ \\ ${ }^{1}$ Department of Geography, University of Mandalay, Mandalay, Mayanmar; ${ }^{2}$ Department of Geography, Hakha College, \\ Haka, Mayanmar; and ${ }^{3}$ Department of Meteorology and Hydrology, University of Mandalay, Mandalay, Mayanmar. \\ *Correspondence: maythunaing1@gmail.com (Dr. May Thu Naing, Associate Professor, Department of Geography, Uni- \\ versity of Mandalay, Mandalay, Mayanmar).
}

\begin{abstract}
This research emphasizes the cause of landslides that occur in Hakha Town and it's environ. The main aim is to investigate the distinct phenomena that result in a landslide and to provide suggestions that can reduce the risk of landslide in its prone area. Regarding the two phenomena, natural and man-made, the data on soil, steep slope, monsoon rainfall, pine forest areas, water sources, motor-car road area, population, and houses were collected by field survey, observation, and questionnaires. The collected data were processed and analyzed by using remote sensing methods, qualitative and quantitative methods, and Geographic Information System. According to the results, major causes of the landslides in the study area are found to be due to location lying between 1,830 meters $(6,000 \mathrm{ft})$ and 2,440 meters $(8,000 \mathrm{ft})$ above sea level and establishing of the settlements on steep slopes, receiving plenty of rainfall under the mountain climate with extremely cold winter season, the existence of unstable and unconsolidated soil and lithology, extending construction of new roads and expansion of the existing roads, population growth and settling of more people in the urban area, and collapsing of big old pine trees. In conclusion, landslides in the study area are found resulting from combined activities of physical factors and human impacts.
\end{abstract}

Keywords: Landslide, Prone area, Hakha, Lithology, Rainfall, Susceptibility, Collapsing, and Human impacts.

\section{INTRODUCTION:}

This research paper analyzes the effect of 2015 landslide that occurred in Hakha due to heavy torrential rain followed by mudflow resulting in erosion, falling down of large trees, and collapsing of buildings and human settlements (Sekhar et al., 2008). Firstly, major cause of the landslide is examined and suggestions are provided in order to prevent landslides, to implement the town growth plans, to mitigate the effect of landslides, and to reduce the risks, by giving local residents the knowledge on possible ways that may cause landslides (Sekhar et al., 2008). Field observation shows that landslides occurred at nine places in Hakha: one UniversePG I www.universepg.com was near the Hakha-Gangaw Road, another one near the Hakha-Htantalan Road, one in Myohaung Quarter, one near the Youths Training School, one at Ministers' Housing Estate in Myothit Quarter, one in Zaythit Quarter, one at Rong Hill, one at Sutaung Hill and one on the Circular Road of the town. From a geographical point of view, those that have caused landslide events in Hakha are found to be physical factors and human factors. The former includes presence of (1) steep slopes susceptible to erosion, (2) soil creep and debris flow, (3) joints in parent material rock, (5) seepage of groundwater due to increasing pore water pressure, (4) lying in the intermountain valley and (6) occurrence of 
heavy rainfall (Sekhar et al., 2008). The latter factors are those of the reclamation of shifting farms locally known as Taungya, the establishment of human settlements, and the construction of roads, ditches, and urban infrastructure (Tiziano Tempesta, 2010).

In this study, of the factors that cause landslides, rainfall threshold values are more emphasized. The study used rainfall probability to evaluate future landslide hazards (Sekhar et al., 2008). First, a database was established by calculating landslide-related items in the study area (Lee et al., 2014). Second, a susceptibility map of the study area was created taking into account the rainfall probability for future recurrence interval days, months, and years (Lee et al., 2014).

Thirdly, the rainfall probability of the study area was calculated. Finally, the susceptibility and hazard maps of the study area were validated (Lee et al., 2016). The study area was the hill region (altitude above sea level: max $2301 \mathrm{~m}$ and min $1582 \mathrm{~m}$ ), composed of a valley in a mountainous terrain with a river flowing through within $30 \mathrm{~m}$ of the road. Geologically, the area consists mainly of banded Trassic and cretaceous. Soils are Chill Hill complex soil and sandy loam, rocky loam, rocky sandy loam, and very rocky loam in order of decreasing abundance. In the period 26- 31 July 2015, the study area with heavy storms and heavy rainfall.

Daily rainfall reached $182 \mathrm{~mm}$; with a cumulative rainfall over sever days of $332 \mathrm{~mm}$. For the form of the landslide in the study area, the total length was on average about $500 \mathrm{~m}$. During the period 28-31 July 2015, 9 landslides were recorded, 732 houses caused property damage. The study area is where many tribes of Chin National live traditionally depending on physical factors such as mountains and coolness. Some settled along the main roads and some on high hill ridges having cultivable lands. The economic development of the area still delays and is also late although the population is growing with increasing rate and in-migration to urban areas from the rural areas. The majority of people are engaged in shifting cultivation being practiced with cattle. This type of cultivation and the presence of beautiful natural scenery of mountains are potentials for the development of the tourism industry (Tiziano Tempesta, 2010).

UniversePG I www.universepg.com

\section{Literature Review}

In the paper titled Landslide Susceptibility Assessment along the Oaktwin-Paukkhaung Road within Khabaung Reserved Forest Area by Dr. Htun Ko (2013), terrain degradation, slope instability, condition of steep slopes, rainfall and run-off along the slopes in various aspects and infiltration rates of the soils have been studied by using Principal Component Analysis (Sekhar et al., 2008). Tun Naing Zaw et al. (2013) also presented types and causes of landslides in their paper named "Landslide Hazard Potentials along the Railway Road between Kywedason and Pyinyaung in Thazi Township of Mandalay Region”. Fell et al. (2008) defined landslide susceptibility, hazard, and risk. Landslide susceptibility is a quantitative and qualitative assessment of the classification, volume (or area), and spatial distribution of landslides which exist or potentially may occur in an area Mihai Ciprian Margarint, (2013). These susceptibility maps have a limit as to predict the hazard area according to rainfall in a real situation because susceptibility maps do not reflect the correlation between landslides and rainfall (Lee $e t$ al., 2014). Thus, research on mapping landslide hazard maps is necessary by considering rainfall data that has a major influence on landslide occurrence (Lee et al., 2014). Further readings are given to "Research on the Calculation of Rainfall Probability Predictions" (Borga, 2002) and Studies Focused on Water Resources (Herr \& Krzysztofowicz, 2005), (Fell et al., 2008) and (Chris P. Potos, 1983). However, in some cases, rainfall probability cannot be used in various areas (Lee et al., 2013) used rainfall probability in analyzing the susceptibilities of landslides (Tiziano Tempesta, 2010).

In this research, daily rainfall data of July are analyzed by using running means and cumulative figures and the results are produced. Moreover, landslide hazard map has also been produced based on rainfall through temporal analysis (Bagchi et al., 2020).

\section{Aims and Objectives}

The aims are to investigate the distinct phenomena of the landslide cause and to establish precipitation thresholds for landslide initiation and validate the results in a part of the Hakha Area. The main objectives are to generate a relevant landslide database for rainfall threshold analysis, to understand the influence of rainfall on shallow landslide initiation and establish precipitation 
thresholds, by correlating rainfall data with landslide dates and to suggestions the reducing of the risk of landslide in its prone area.

\section{METHOLODOGY:}

Primary data are collected from the residents of the town and village tracts, by interviewing, using questionnaires and surveying and measuring at GPS sample points. Secondary data are obtained from the government offices, Records of the Township's Administrative Department, and Town's Development Committee while some are taken from various departments' records and the Reports of Myanmar Geoscience Society. According to the UTM Map No.2293 10, the study area in the vicinity of Hakha and lies between $22^{\circ} 30^{\prime}$ North and $22^{\circ} 45^{\prime}$ North Latitude and between $93^{\circ} 30^{\prime}$ East and $93^{\circ} 45^{\prime}$ East Latitude. Within the area, forty sites are chosen and surveyed. Relevant topical maps, including those of topography, geology, and soil and forest cover, are available either in print or in electronic form, at different scales and formats, in Mandalay University's library (Chris P. Potos, 1983). The study used a landslide map showing point coverage, a map with polygon coverage, and 1:25,000 scale. Rainfall factors related to landslides were considered in the calculation the landslide probability or rainfall thread hold level in statistical methods. To calculate the rainfall probability accurately, understanding the accuracy of past weather data is important (Wallace, 1895). Rainfall probability in the study area was analyzed along with daily rainfall data taken over 21 years (from January 1998 to December 2018). For more accurate analysis of future rainfall probabilities, the quality and quantity of past rainfall data are a significant influence and may serve to enhance accuracy. For the study area, the total grid number was (716) and the selected landslide occurrence location grid was (72).

Table 1: The Samples of Field Study in Landslide Area in Hakha (Source: Field Observation in 2019).

\begin{tabular}{|c|c|c|c|c|c|}
\hline Sr. No & Latitude (East) & Longitude (North) & Sr. No & Latitude (East) & Longitude (North) \\
\hline 1 & $22^{\circ} 45^{\prime} 45^{\prime}$ & $93^{\circ} 34^{\prime} 15^{\prime}$ & 21 & $22^{\circ} 15^{\prime} 02^{\prime}$ & $93^{\circ} 35^{\prime} 49^{\prime}$ \\
\hline 2 & $22^{\circ} 46^{\prime} 02^{\prime}$ & $93^{\circ} 34^{\prime} 07^{\prime}$ & 22 & $22^{\circ} 15^{\prime} 02^{\prime}$ & $93^{\circ} 35^{\prime} 48^{\prime}$ \\
\hline 3 & $22^{\circ} 33^{\prime} 59^{\prime}$ & $93^{\circ} 34^{\prime} 33^{\prime}$ & 23 & $22^{\circ} 15^{\prime} 02^{\prime}$ & $93^{\circ} 35^{\prime} 48^{\prime}$ \\
\hline 4 & $22^{\circ} 38^{\prime} 31^{\prime \prime}$ & $93^{\circ} 34^{\prime} 37^{\prime}$ & 24 & $22^{\circ} 15^{\prime} 02^{\prime}$ & $93^{\circ} 35^{\prime} 49^{\prime}$ \\
\hline 5 & $22^{\circ} 38^{\prime} 35^{\prime}$ & $93^{\circ} 36^{\prime} 21^{\prime \prime}$ & 25 & $22^{\circ} 15^{\prime} 01^{\prime \prime}$ & $93^{\circ} 35^{\prime} 44^{\prime}$ \\
\hline 6 & $22^{\circ} 38^{\prime} 34^{\prime \prime}$ & $93^{\circ} 37^{\prime} 01^{\prime \prime}$ & 26 & $22^{\circ} 15^{\prime} 02^{\prime}$ & $93^{\circ} 35^{\prime} 50^{\prime}$ \\
\hline 7 & $22^{\circ} 38^{\prime} 34^{\prime}$ & $93^{\circ} 37^{\prime} 03^{\prime}$ & 27 & $22^{\circ} 15^{\prime} 03^{\prime}$ & $93^{\circ} 35^{\prime} 41^{\prime \prime}$ \\
\hline 8 & $22^{\circ} 38^{\prime} 45^{\prime}$ & $93^{\circ} 36^{\prime} 40^{\prime}$ & 28 & $22^{\circ} 15^{\prime} 01^{\prime \prime}$ & $93^{\circ} 35^{\prime} 46^{\prime}$ \\
\hline 9 & $22^{\circ} 38^{\prime} 27^{\prime}$ & $93^{\circ} 36^{\prime} 40^{\prime}$ & 21 & $22^{\circ} 15^{\prime} 02^{\prime}$ & $93^{\circ} 35^{\prime} 49^{\prime}$ \\
\hline 10 & $22^{\circ} 38^{\prime} 41^{\prime \prime}$ & $93^{\circ} 36^{\prime} 37^{\prime}$ & 22 & $22^{\circ} 15^{\prime} 02^{\prime}$ & $93^{\circ} 35^{\prime} 48^{\prime}$ \\
\hline 11 & $22^{\circ} 38^{\prime} 40^{\prime}$ & $93^{\circ} 36^{\prime} 38^{\prime}$ & 23 & $22^{\circ} 15^{\prime} 02^{\prime}$ & $93^{\circ} 35^{\prime} 48^{\prime}$ \\
\hline 12 & $22^{\circ} 39^{\prime} 05^{\prime}$ & $93^{\circ} 35^{\prime} 18^{\prime}$ & 24 & $22^{\circ} 15^{\prime} 02^{\prime}$ & $93^{\circ} 35^{\prime} 49^{\prime}$ \\
\hline 13 & $22^{\circ} 39^{\prime} 32^{\prime}$ & $93^{\circ} 35^{\prime} 01^{\prime \prime}$ & 25 & $22^{\circ} 15^{\prime} 01^{\prime \prime}$ & $93^{\circ} 35^{\prime} 44^{\prime}$ \\
\hline 14 & $22^{\circ} 40^{\prime} 23^{\prime}$ & $93^{\circ} 35^{\prime} 12^{\prime}$ & 26 & $22^{\circ} 15^{\prime} 02^{\prime}$ & $93^{\circ} 35^{\prime} 50^{\prime}$ \\
\hline 15 & $22^{\circ} 40^{\prime} 23^{\prime}$ & $93^{\circ} 35^{\prime} 11^{\prime \prime}$ & 27 & $22^{\circ} 15^{\prime} 03^{\prime}$ & $93^{\circ} 35^{\prime} 41^{\prime \prime}$ \\
\hline 16 & $22^{\circ} 40^{\prime} 20^{\prime \prime}$ & $93^{\circ} 35^{\prime} 05^{\prime}$ & 28 & $22^{\circ} 15^{\prime} 01^{\prime \prime}$ & $93^{\circ} 35^{\prime} 46^{\prime \prime}$ \\
\hline 17 & $22^{\circ} 40^{\prime} 20^{\prime}$ & $93^{\circ} 35^{\prime} 02^{\prime}$ & 29 & $22^{\circ} 15^{\prime} 02^{\prime}$ & $93^{\circ} 35^{\prime} 49^{\prime}$ \\
\hline 18 & $22^{\circ} 40^{\prime} 21^{\prime \prime}$ & $93^{\circ} 35^{\prime} 11^{\prime \prime}$ & 30 & $22^{\circ} 15^{\prime} 02^{\prime}$ & $93^{\circ} 35^{\prime} 48^{\prime}$ \\
\hline 19 & $22^{\circ} 40^{\prime} 20^{\prime}$ & $93^{\circ} 35^{\prime} 10^{\prime}$ & 31 & $22^{\circ} 15^{\prime} 13^{\prime}$ & $93^{\circ} 35^{\prime} 07^{\prime}$ \\
\hline 20 & $22^{\circ} 40^{\prime} 22^{\prime}$ & $93^{\circ} 35^{\prime} 13^{\prime \prime}$ & 32 & $22^{\circ} 15^{\prime} 01^{\prime \prime}$ & $93^{\circ} 35^{\prime} 48^{\prime}$ \\
\hline 21 & $22^{\circ} 15^{\prime} 02^{\prime}$ & $93^{\circ} 35^{\prime} 49^{\prime}$ & 33 & $22^{\circ} 15^{\prime} 13^{\prime}$ & $93^{\circ} 35^{\prime} 00^{\prime}$ \\
\hline 22 & $22^{\circ} 15^{\prime} 02^{\prime}$ & $93^{\circ} 35^{\prime} 48^{\prime}$ & 34 & $22^{\circ} 15^{\prime} 01^{\prime \prime}$ & $93^{\circ} 35^{\prime} 48^{\prime \prime}$ \\
\hline 23 & $22^{\circ} 15^{\prime} 02^{\prime}$ & $93^{\circ} 35^{\prime} 48^{\prime}$ & 35 & $22^{\circ} 15^{\prime} 10^{\prime}$ & $93^{\circ} 35^{\prime} 52^{\prime}$ \\
\hline 24 & $22^{\circ} 15^{\prime} 02^{\prime}$ & $9335^{\prime} 49^{\prime}$ & 36 & $22^{\circ} 15^{\prime} 10^{\prime}$ & $93^{\circ} 35^{\prime} 50^{\prime}$ \\
\hline 25 & $22^{\circ} 15^{\prime} 01^{\prime \prime}$ & $93^{\circ} 35^{\prime} 44^{\prime \prime}$ & 37 & $22^{\circ} 15^{\prime} 01^{\prime \prime}$ & $93^{\circ} 35^{\prime} 43^{\prime}$ \\
\hline 26 & $22^{\circ} 15^{\prime} 02^{\prime}$ & $93^{\circ} 35^{\prime} 50^{\prime}$ & 38 & $22^{\circ} 15^{\prime} 01^{\prime \prime}$ & $93^{\circ} 35^{\prime} 47^{\prime}$ \\
\hline 27 & $22^{\circ} 15^{\prime} 03^{\prime}$ & $93^{\circ} 35^{\prime} 41^{\prime \prime}$ & 39 & $22^{\circ} 15^{\prime} 02^{\prime}$ & $93^{\circ} 35^{\prime} 23^{\prime}$ \\
\hline 28 & $22^{\circ} 15^{\prime} 01^{\prime \prime}$ & $93^{\circ} 35^{\prime} 46^{\prime}$ & 40 & $22^{\circ} 15^{\prime} 02^{\prime}$ & $93^{\circ} 35^{\prime} 24^{\prime \prime}$ \\
\hline
\end{tabular}


The research methodology is the spatial precipitation thresholds for slope failure instigation and applying them in GIS to model the susceptible slope in the area.

\section{Research Problems}

Why did the important factors of land cause the landslide problems in Hakha and its environs?

\section{Study Area}

Hakha is the capital of Chin State and Hakha Township lies between $22^{\circ} 01^{\prime}$ North and $22^{\circ} 50^{\prime}$ North Latitude and between $93^{\circ} 32^{\prime}$ East and $94^{\circ} 45^{\prime}$ East Latitude. The town is 128 miles south of Kalay and is connected with Kalay in Sagaing Region and Gangaw in Magway Region by seasonal roads. The town which is composed of eight quarters has an area of 12.80 square kilometers (7.94 square miles) and its rural area is 4,144.76 square kilometers (1600.30 square miles). The township extends for 36 miles in east-west and 45 miles in a north-south direction (Chris P. Potos, 1983). The study area lies within the town and its environment. The study area is located on the Western Mountain Range of Myanmar which is the continuation of the Himalayas, the youngest folded mountain in the world. The township lies between $914 \mathrm{~m}$ (3,000 feet) and 2,438 $\mathrm{m}(8,000$ feet) above sea level and Hakha Town at $1,865 \mathrm{~m}(6,120$ feet). The township is hilly and mountainous. On the hills, Bwaypa $(2,704 \mathrm{~m}$ or 8,873 feet), Rhone $(2,031 \mathrm{~m}$ or 7,849 feet), Seinmu $(2,042 \mathrm{~m}$ or 6,700 feet) and Pawpi $(1,951 \mathrm{~m}$ or 6,402 feet) are the distinguished hills.

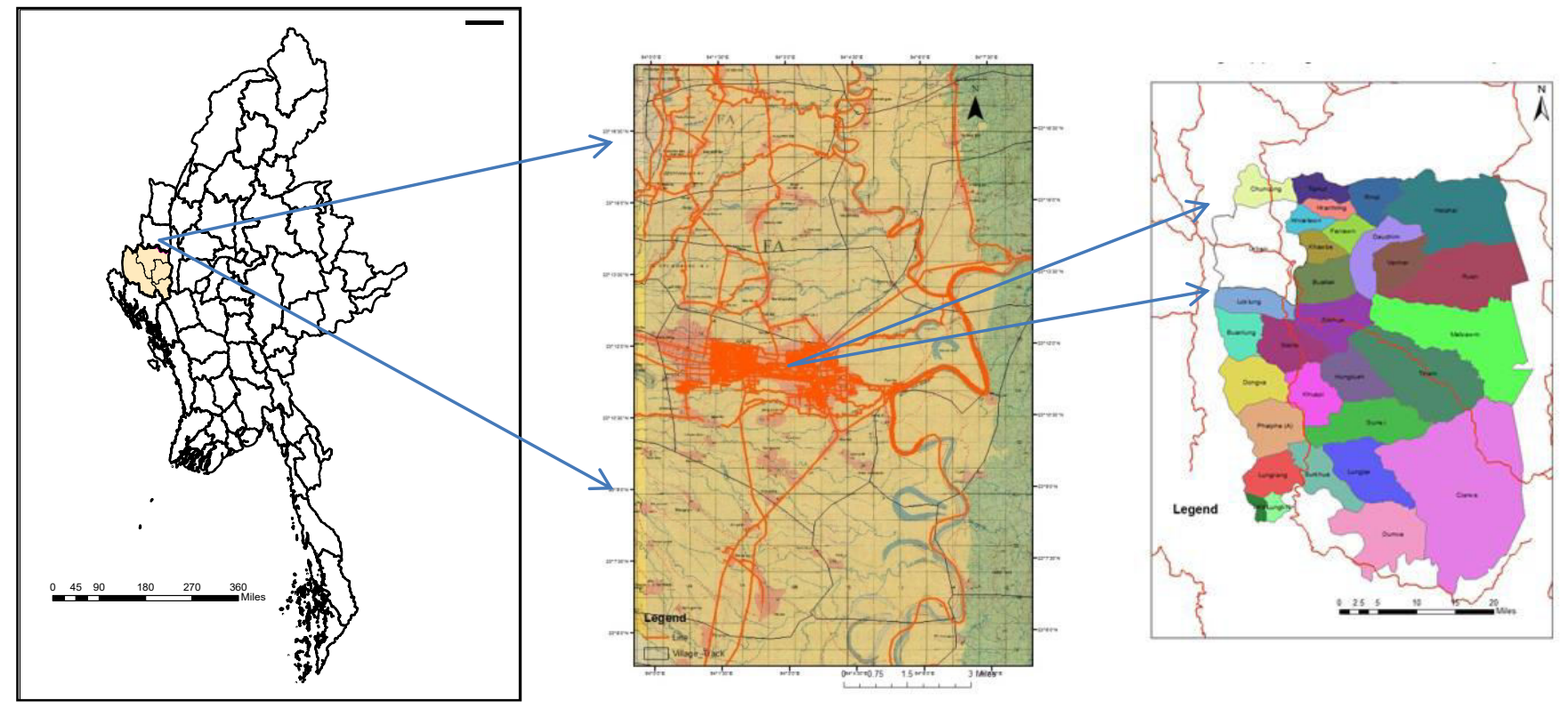

Fig. 1: Location Map of Hakha Area (Source: Department of General Administrative, Hakha Township, 2015).

\section{RESULTS AND FINDINGS:}

Hakha area usually experiences natural disasters such as earthquakes and landslides. The landslide causes damage to buildings and houses. The distinct one is in July 2015. It resulted in the collapse of 732 houses. The landslide was derived from combined activities of urbanization, overproducing of forest products, and mainly heavy rain that prevailed within 4-5 days continuously. The landslides came out from the following local geographical basic factors (Wallace, 1895).

\section{Topography}

Hakha Township lies on the Western Mountains of Myanmar which extend in north-south at an elevation

UniversePG I www.universepg.com of 1830-2440 meter or 6,000-8,000 feet above sea level. The mountains exist as rolling hills whose slopes are steep about $30^{\circ}$ and above. Rhung Hill, lying east of Hakha is 2,031 m (7,849 feet) above sea level and its slopes are steep. Hakha is established on its watershed slopes. Houses have been built on $70-90^{\circ}$ slopes which have been leveled as small terraces (Wallace, 1895). According to Salter et al. (1981), a landslide can never take place on slopes less than $8^{\circ}$ but more than $20^{\circ}$ and it can initiate on $20^{\circ}-25^{\circ}$ slopes Kate Mickelson, (1984).

\section{Drainage}

Drainage is another factor. In the northern portion of Hakha Town, Rawi Stream flows from south to north, 
Tawng Stream from west to east and the two enter the Dawn Stream. In the southwest portion of Hakha Township Boinu River, a tributary of Kaladan River flows into Timit Stream after joining with Nawi Stream and goes on from south to north. Drinking and domestic water of the town is obtained from Timit Stream and more than 20 natural springs seeping from hill-slopes. In some places, debris fallen from hill-slopes usually block gullies and form natural dams. During heavy rain, that debris becomes weak, and sometimes debris flow and mudflow come out.

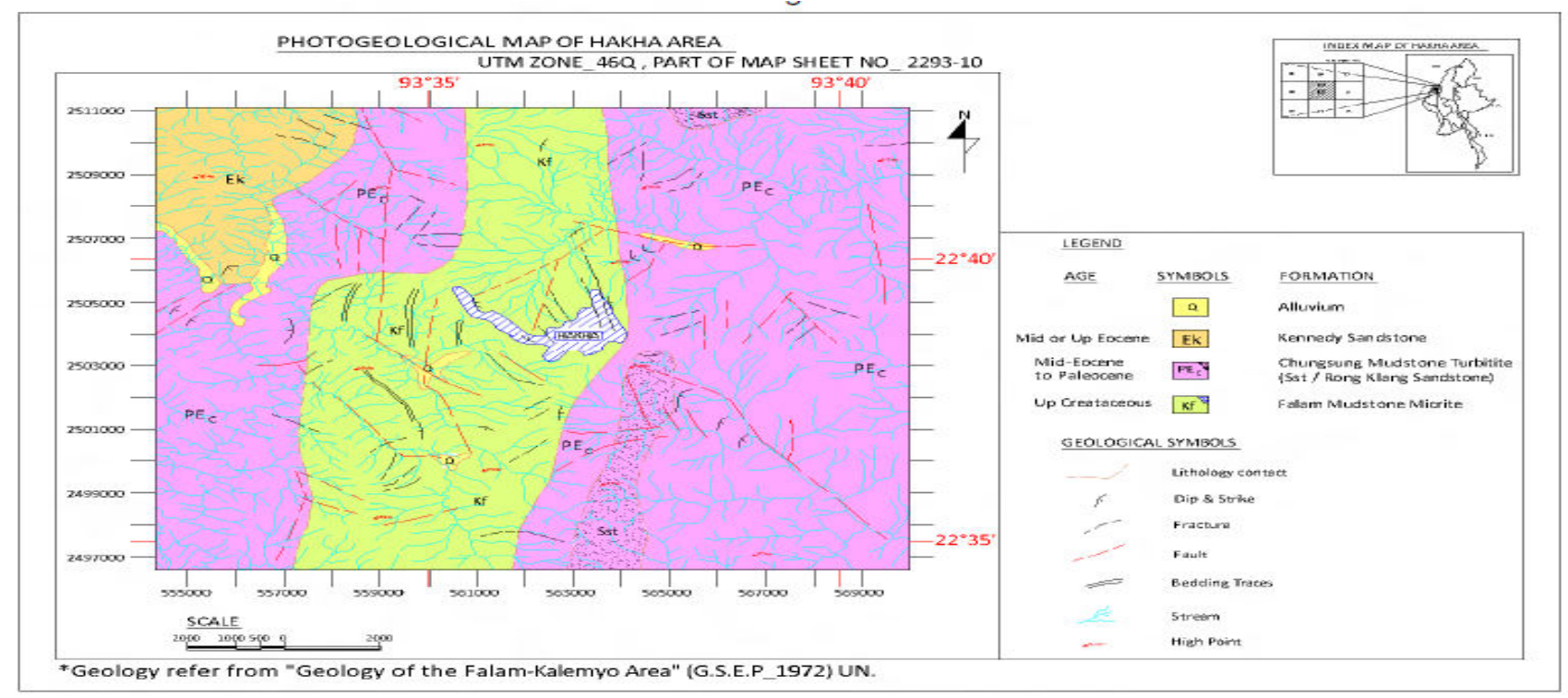

Fig. 2: Topography and Drainage of Hakha Area (Source: DEM 30 Meter, UTM Zone 46, Map 2293 10).

\section{Climate and Vegetation}

Climate and vegetation of Hakha appear to favor landslide occurrence. The climate of the town is very cold in winter with a mean temperature of $5^{\circ} \mathrm{C}-15^{\circ} \mathrm{C}$; sometimes lower than $-4^{\circ} \mathrm{C}$. It is cool in summer with a mean temperature of $21^{\circ} \mathrm{C}-29.5^{\circ} \mathrm{C}$ (Wallace, 1895). The town gets an annual rainfall of $937.5 \mathrm{~mm}(37.5$ inches) with average rainy days of 63 . Much of rain and more rainy days occur in high places especially in Monsoon season or rainy season. In the area higher than $1,850 \mathrm{~m}$, even sleet is found in winter and heavy rain consecutively in the rainy season. Hakha region has a humid mountain climate with an annual rainfall of 2,540mm (100 inches). On $30^{\text {th }}$ and $31^{\text {st }}$ July 2015, a small cyclone that emerged in the Bangal Bay moved toward the northwest and ran into the Chin State, leaving heavy rain, followed by floods and landslides. In that year it got $698.5 \mathrm{~mm}$ (27.5 inches) more than annual prevailing rainfall and rainy days also exceeded by 11 days than annual rainy days. Consequently, it caused landslides on Rhung Hill and in some quarters of Hakha. Common natural vegetation in the Hakha region is pine, rhododendrons, mosses, lichens, wildflowers, spruce, fir, and orchids.

\section{Soil Conditions in Hakha}

Surface soil is gravelly one, underlain by shale and slate rock layers. In other words, it is residual soil and colluvial deposits, formed under the weathering process. In Zaythit Quarter of Hakha, landslide occurrence was found due to increasing pore water pressure as some patches of surface soils were over the slate layer. The hill area on which Hakha lies is formed of young mudstone which has fluid property and its cohesive power lowers to zero, allowing easy infiltration of water into the soil when it is wet. Thus sand and debris mixed with soil become loose and finally bring about the landslide.

\section{Geological Condition in Hakha}

There are three types of rocks in the eastern margin of Indo-Burman Ranges.

1) Kennedy Sandstone Formation occurs in the northeast portion of Hakha, extending in north-south alignment along the Road to Falam. It is formed of the layers of sandstone and mudstone including mica crystal.

2) Chunsung Mudstone-Turbidite Formation is outcropping at Chungsung, located in the northwest of 
Hakha. It is about $1.83 \mathrm{~m}$ (6 feet) thick and contains mud a lot within the sandstone.

3) Falam Mudstone-Micrite Formation lies along the Road to Falam Township and is about 15 feet thick.

It is formed of lime, calcareous and carbonaceous rocks. Its dip is nearly right angle and, in some places, over-turned structure is found (Wallace, 1895). The mudstone layers are composed of indurate shale and sandstone. When rain is heavy, the layer come into dispersive nature and causes a landslide. In the regional geological setting, folds caused by tectonic movement are dipping mostly from west to east and some from east to west (Geological Setting, 2011).

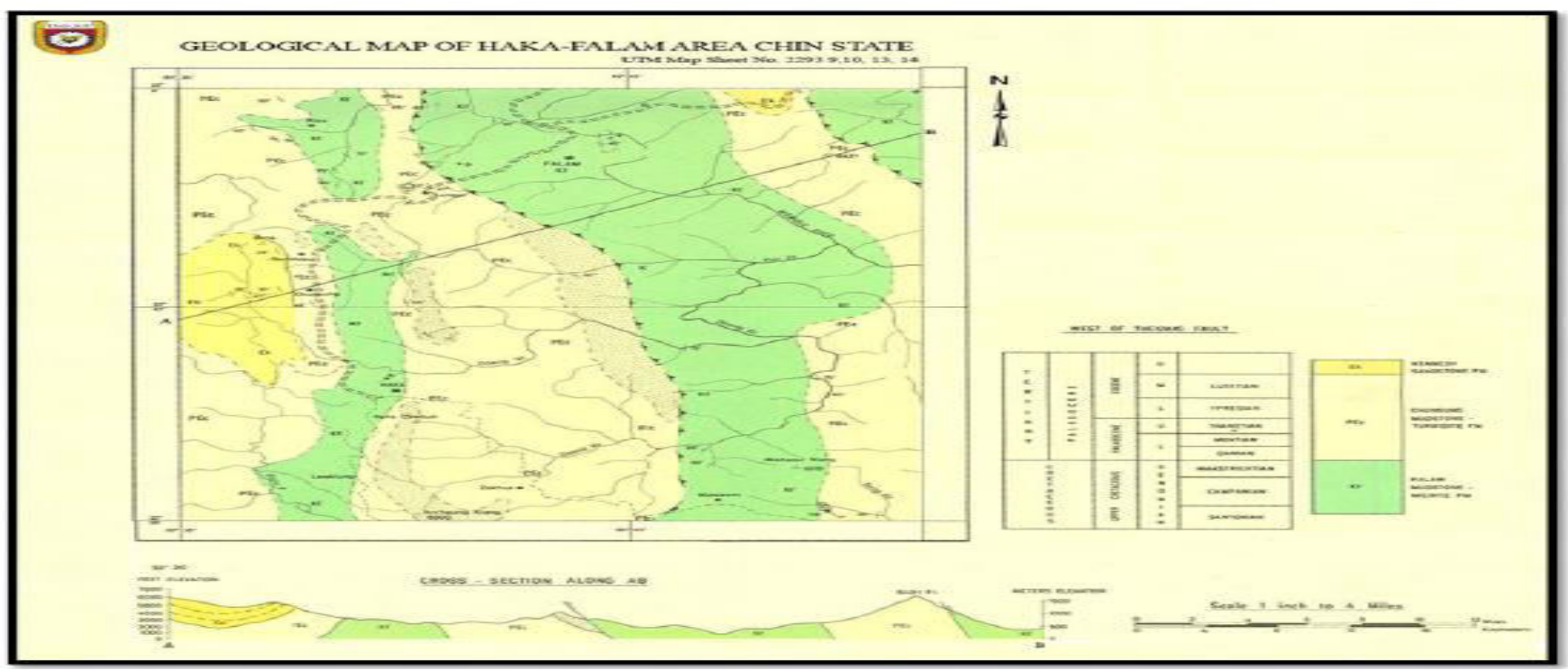

Fig. 3: Regional Geological Setting in Hakha Area of Chin State (Source: UTM 2293 9,10,12,14 Myanmar Erath science Society Report, in 2015).

In the vicinity of Hakha, the followings occur (1) existence of $3 \mathrm{~cm}$ to $30 \mathrm{~cm}$ thick severely weathered debris mixed with earth and rocks, (2) presence of thin laminar structure of earth and mudstone eroded under severe climatic condition, (3) occurrence of weathered debris in situ, (4) appearance of parent material without having eroded yet and (5) a lot of joints in rock layers. A lot of joints that occur in rock layers of slopes of Rhung Taung appear to force the initial process of landslides and successive sliding onto the gullies when rainwater penetrates the joints

\section{Analysis on Landslide in Associated with Popul- ation and Houses}

In 2015 there lived a total population of 39,643 persons in a total of 8,754 houses, with a population density of 1,212 persons per square kilometer $(3,139$ persons/square mile) and with house density of 60 houses per square kilometer (156 houses per square kilometer). Of these, collapsed ones due to 2015 landslide amounted to 410 houses and those unsuitable for living on to 322 houses. In 2017, eight (new two) quarters were extended and thus urban area of Hakha became UniversePG I www.universepg.com
86.92 sq.km (33.56 sq.mile) from 20.56 sq.km (7.94 sq.mile) in 2015. In 2019 urban population of Hakha had grown to 43,772 persons and the houses to 5,641 units. Population density was 504 persons per square kilometer (1,304 persons per sq.mile) and house density was 65 units per square kilometer in 2019, Table 2 and Mihai Ciprian Margarint, (2013).

Table 2: Population Growth and Household, 2015 (Source: HCDC Hakha Development Committee in Hakha Area).

\begin{tabular}{|c|c|c|c|c|c|}
\hline \multirow{2}{*}{ Sr } & \multirow{2}{*}{$\begin{array}{c}\text { Ward/Village } \\
\text { Tract }\end{array}$} & \multicolumn{2}{|c|}{\begin{tabular}{c}
\multirow{2}{*}{ Population } \\
\multirow{2}{*}{ House }
\end{tabular}} & \multirow{2}{*}{ Household } \\
\cline { 3 - 4 } & & $\mathbf{2 0 1 5}$ & $\mathbf{2 0 1 9}$ & & \\
\hline 1 & Zay Haung(W) & 2649 & 2649 & 305 & 487 \\
\hline 2 & Zay Thit(W) & 16668 & 16668 & 1174 & 2090 \\
\hline 3 & Pyi Taw Thar(W) & 5004 & 5004 & 407 & 805 \\
\hline 4 & Kyaw Boke(W) & 1979 & 1979 & 267 & 270 \\
\hline 5 & Myo Haung(W) & 9215 & 9215 & 49 & 53 \\
\hline 6 & Myo Thit(W) & 4128 & 4128 & 360 & 678 \\
\hline 7 & Hakha Htar (1) & - & 1896 & 414 & 421 \\
\hline 8 & Hakha Htar (2) & - & 2233 & 418 & 429 \\
\hline & Urban Total & 39,643 & 43,772 & 3,394 & 5,233 \\
\hline
\end{tabular}




\section{Road Network and Settlement}

From Hakha, Kalay can be reached to the north, Gangaw to the south, Mindat to the southeast via Matupi. In 2014 main roads connected to those towns were upgraded to concrete roads, then, along which most of the people moved from the hills and settled (Wallace, 1895). Human activities such as leveling of hill-slopes for construction of roads and buildings and felling trees resulted in changes of ground structure. Within the total town area (20.565 Sq.km or 7.94 sq.mile) of Hakha, there were 60,690 metres $(19,910$ feet $)$ of tarred road, $10,100 \mathrm{~m}(33,135$ feet $)$ of metalled roads, $31,080 \mathrm{~m}$ (101,970 feet) of earth road, totaling the length of $101,870 \mathrm{~m}$ (155,015 feet). Thus road density was $5.95 \mathrm{~km}$ per square kilometer (3.7 miles/sq.mile) in Hakha. According to Jun Yang (2018), it is known that the road density of the town is high in urban land-use intensity.

\section{Analysis of Precipitation Thresholds for Landslide in Hakha Area}

Precipitation thresholds for initiation of failure in slope have been assessed in many regions of the world, based on a combination of landslide and rainfall information (Sekhar et al., 2008). Attempts have been made towards the prediction of landslide initiation using intensity- duration data for rainstorms (Caine, 1980; Dai and Lee, 2001). The significance of antecedent rainfall in landslide initiation is also recognized (Glade, 1997) and (Nader et al., 2015). Statistically, the critical rainfall amounts have also been established, when an elaborate information on rainfall and landslide occurrence is available (Chleborad, 2003: Lim et al., 1991: Terlien, 1998b). Hakha area gets monsoon rain starting from May. If the rain exceeds the precipitation threshold, it causes a landslide. Geomorphologically, rainfall intensity is found directly related to landslide. According to the daily rainfall data, it rained in Hakha about $1,151 \mathrm{~mm}$ in July 2015. This amount was more than monthly rainfalls of July that occurred within the years of 1998-2018 and so it caused a landslide on hill-slopes along the main road (Wallace, 1895). Subsequently, houses and buildings collapsed.

In fact, $780 \mathrm{~mm}$, rainfall received from $26^{\text {th }}$ to $31^{\text {st }} \mathrm{July}$ 2015, represented 68 percent of July rainfall $(1,151$ $\mathrm{mm})$ and exceeded average monthly rainfall $(45.3 \mathrm{~mm})$ of July. Moreover, it was 32 percent of annual rainfall UniversePG I www.universepg.com
$(2,406 \mathrm{~mm})$ of Hakha. Such exceeding caused landslide in Hakha.

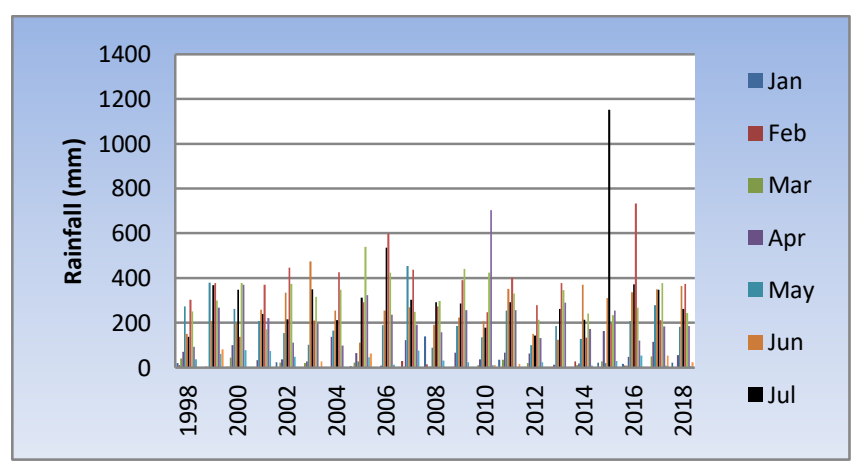

Fig. 4: Monthly Rainfall Distribution between 19982018 (Source: Based on Table 3).

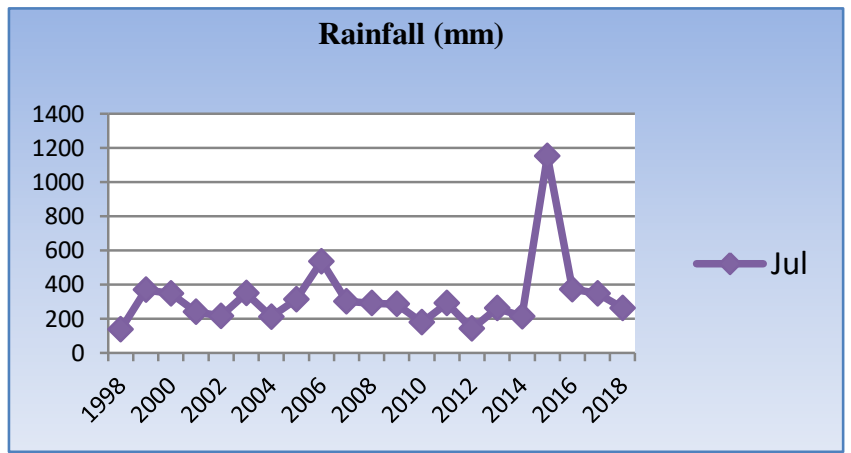

Fig. 5: July Rainfall in Hakha Area 1998-2018.

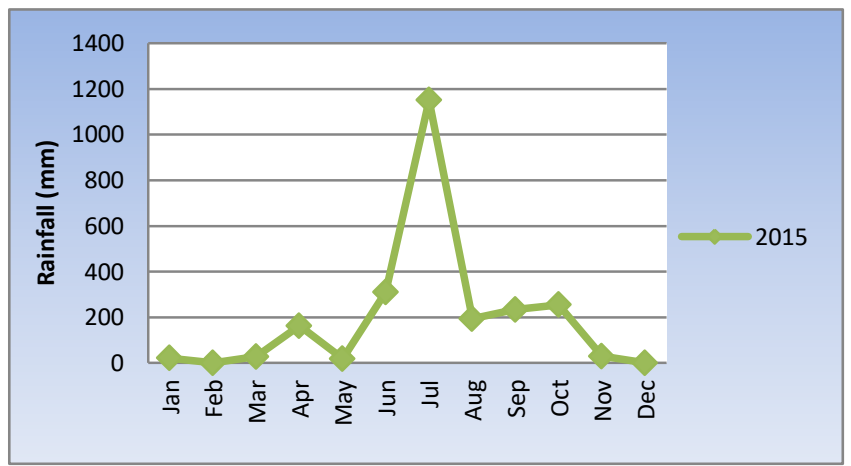

Fig. 6: Monthly Rainfall Distribution in Hakha Township in 2015.

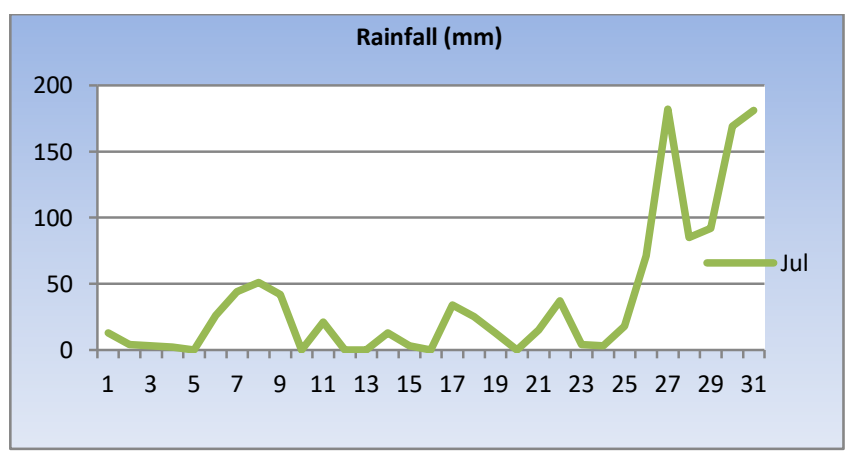

Fig. 7: Daily Rainfall in Hakha Area in July 2015 (Source: Based on Table 2). 
Table 3: Rainfall in monthly 1998- 2018, Hakha Area (Source: Meteorology and Hydrology Department in Mandalay, 2015).

\begin{tabular}{|c|c|c|c|c|c|c|c|c|c|c|c|c|}
\hline YEAR & JAN & FEB & MAR & APR & MAY & JUN & JUL & AUG & SEP & OCT & NOV & DEC \\
\hline 1998 & 20 & 11 & 40 & 71 & 273 & 150 & 137 & 302 & 250 & 93 & 36 & 0 \\
\hline 1999 & 0 & 0 & 5 & 0 & 379 & 208 & 368 & 378 & 299 & 268 & 61 & 82 \\
\hline 2000 & 4 & 3 & 44 & 100 & 262 & 200 & 348 & 138 & 378 & 369 & 77 & 0 \\
\hline 2001 & 0 & 0 & 0 & 33 & 208 & 258 & 239 & 369 & 170 & 220 & 73 & 0 \\
\hline 2002 & 24 & 0 & 22 & 36 & 154 & 335 & 216 & 446 & 373 & 112 & 47 & 1 \\
\hline 2003 & 0 & 1 & 19 & 27 & 101 & 474 & 349 & 210 & 315 & 195 & 0 & 27 \\
\hline 2004 & 0 & 0 & 2 & 138 & 166 & 254 & 211 & 426 & 347 & 98 & 1 & 0 \\
\hline 2005 & 7 & 0 & 21 & 65 & 27 & 112 & 313 & 292 & 540 & 323 & 46 & 62 \\
\hline 2006 & 0 & 0 & 0 & 9 & 189 & 255 & 535 & 598 & 423 & 235 & 12 & 0 \\
\hline 2007 & 0 & 29 & 3 & 123 & 453 & 269 & 302 & 437 & 248 & 191 & 75 & 0 \\
\hline 2008 & 139 & 15 & 2 & 3 & 89 & 191 & 291 & 273 & 297 & 158 & 31 & 0 \\
\hline 2009 & 0 & 0 & 4 & 67 & 185 & 223 & 286 & 391 & 441 & 256 & 24 & 0 \\
\hline 2010 & 0 & 0 & 10 & 36 & 135 & 207 & 178 & 247 & 424 & 703 & 10 & 11 \\
\hline 2011 & 35 & 0 & 35 & 67 & 255 & 351 & 291 & 402 & 331 & 257 & 0 & 17 \\
\hline 2012 & 0 & 0 & 19 & 62 & 99 & 151 & 142 & 278 & 214 & 132 & 23 & 0 \\
\hline 2013 & 0 & 1 & 4 & 12 & 185 & 124 & 261 & 378 & 346 & 290 & 0 & 0 \\
\hline 2014 & 0 & 27 & 11 & 18 & 127 & 369 & 214 & 134 & 241 & 173 & 8 & 0 \\
\hline 2015 & 21 & 0 & 28 & 163 & 19 & 311 & 1151 & 194 & 234 & 255 & 30 & 0 \\
\hline 2016 & 16 & 8 & 8 & 48 & 207 & 336 & 372 & 733 & 267 & 121 & 53 & 0 \\
\hline 2017 & 0 & 0 & 50 & 114 & 278 & 349 & 348 & 211 & 378 & 183 & 9 & 54 \\
\hline 2018 & 21 & 2 & 1 & 56 & 181 & 365 & 262 & 374 & 244 & 186 & 7 & 23 \\
\hline
\end{tabular}

A threshold, minimum or maximum is defined as the limits which a process is most likely to occur (Mihai Ciprian Margarint, 2013). The minimum thresholds are generally established for precipitation induced slope failures to delineate the limit below which they are most unlikely to be triggered, whereas, the maximum thresholds are given to identify the limit exceeding which there is a $100 \%$ probability of landslide occurrence. The landslide triggering rainfall thresholds separate events that results from those which failed to triggered landslides and can be defined on an empirical or on physical bases. Empirical thresholds are generally established based on either of the following parameters, namely rainfall intensity, duration, cumulative precipitation, and the antecedent rainfall or their combinations. In the present study, the precipitation thresholds for landslide initiation are defined based on the relationship between rainfall magnitude reached, over a specified time failure and the cumulative antecedent rainfall i.e., the rainfall accumulation over a specified number of days before the day on which a slope failed (Sekhar et al., 2008). As the landslide taken is situated along the highway, their locations were entered as a kilometer-stone reading on the highway. Traverses along the route were done to verify the data and ascertain its geographic location. A GPS survey was also UniversePG I www.universepg.com carried out to determine the geographic coordinates of every location. It was found during field visit that some of the old rock falls and soil slips, which were reported in the official records, could not be precisely located on ground as no associated scar or evident damage to the retaining wall was noted. Only those incidences were considered which were confirmed by local people. The information on the location, slope, and lithology were also entered using the landslide field data. The Daily, monthly and annual rainfall was calculated. Computations running mean method (Gregory, 1978) were done using Excel to get the 3,5,7. 9,15 days, and 30 days rainfall values in 2015. The corresponding daily, 3, 5, 7.9,15 days, and 30 days rainfall for each landslide day were entered to complete the required database. Landslide data was rearranged for all rainy days, i.e, having at least over 1 $\mathrm{mm}$ of daily rainfall. It was noted that only 25 days experience over $1 \mathrm{~mm}$ of rainfall including 6 landslide days, out of which 15 days has a single landslide event. While multiple events were reported 6 days. To establish thresholds landslide initiation in the study area the database was scrutinized to identify the rainfall magnitudes over different durations to separate combinations of daily and antecedent rainfall that triggered landslides and then establish the probable landslide 
triggering thresholds (Sekhar et al., 2008). A review of the methodology proposed in the literature shows that the number of antecedent days must be carefully selected (Terlien, 1998a). Thus, various antecedent rainfall intervals $(3,5,7,9$ and 15 days prior) were considered to calculate the cumulative antecedent rainfall which influenced landslide initiation the most (Wallace, 1895). The database was rearranged to ob-serve the number of landslides occurring in a day along with the daily rainfall. A comparative analysis was performed to study the relationships between daily and prior 3,5,7,9 days rainfall, daily and prior 15-day rainfall, in 2015 (Chris P. Potos, 1983).

The minimum thresholds for each combination of landslide triggering rainfall cumulative are shown by the green line which is used to demarcate the lower bound precipitation below which no slope failure initiates. These thresholds are identified visually, on the scatter plots between the daily rainfall and the cumulative antecedent rain. The relationship between the landslide occurrences with the daily and the 3 days prior rainfall is defined by running mean (Maung Maung Aye, 1988; Gregory, 1980). Therefore, this is shown to represent a difference between sample means that have occurred by chance with a probability of greater than $10 \%$. Thus in this case the apparent fluctuation involving change in 3,5,7,9 and 15 day means of the order of nearly $(272 \mathrm{~mm})$ can be accepted as statistically valid, and further evidence must be sought before such (a fluctuation will be accepted as a reasonable possibility (Wallace, 1895).

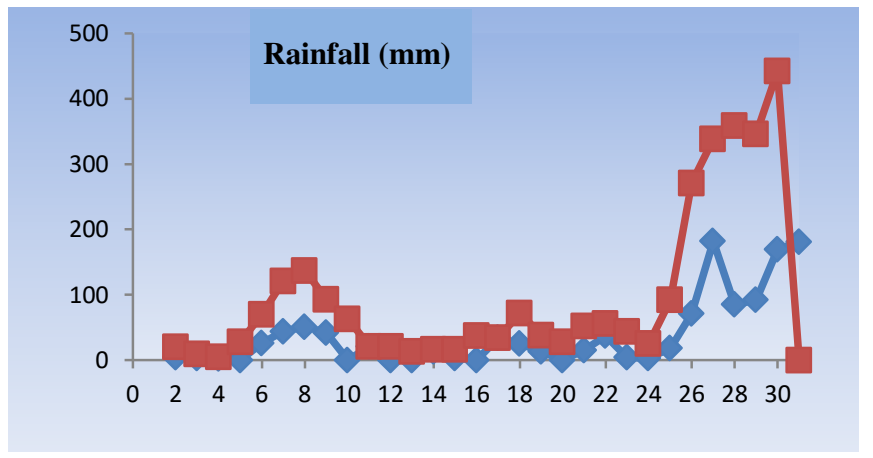

Fig. 8: 3- day running means for daily rainfall at Hakha, July 1- 312015 (Source: Table 4).

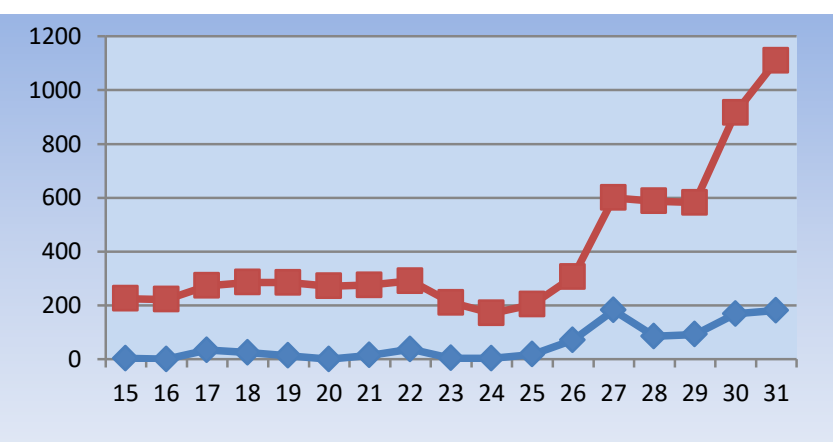

Fig. 9: 7- day running means for daily rainfall at Hakha, July 1- 312015 (Source: Table 4).

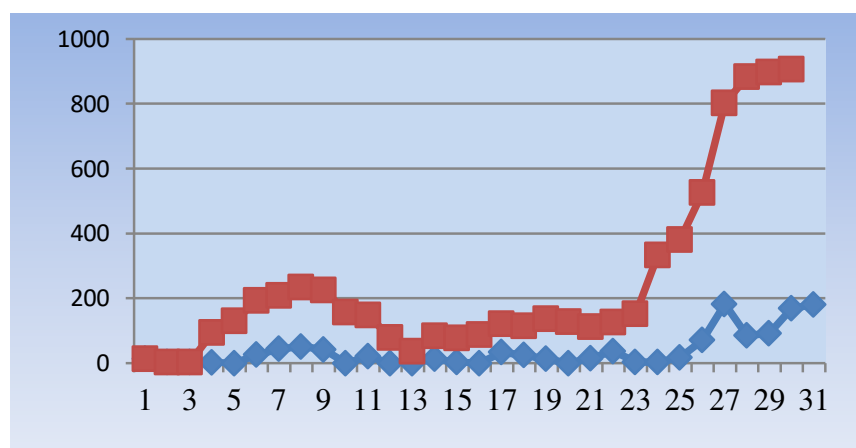

Fig. 10: 9- day running means for monthly rainfall at Hakha, July 1- 312015 (Source: Table 4).

Table 4: Calculation on Running Mean for Rainfall Susceptibility in Hakha (mm), July 2015 (Source: Meteorology and Hydrology Department of Mandalay Region, 2015).

\begin{tabular}{|c|c|c|c|c|c|c|c|}
\hline Day & $\begin{array}{c}\text { Actual } \\
\text { Rainfall }\end{array}$ & $\begin{array}{c}\text { Accumulative } \\
\text { Rainfall }\end{array}$ & $\begin{array}{c}\text { 3-Day } \\
\text { Running } \\
\text { Mean }\end{array}$ & $\begin{array}{c}\text { 5-Day } \\
\text { Running } \\
\text { Mean }\end{array}$ & $\begin{array}{c}\text { 7-Day } \\
\text { Running } \\
\text { Mean }\end{array}$ & $\begin{array}{c}\text { 9-Day } \\
\text { Running } \\
\text { Mean }\end{array}$ & $\begin{array}{c}\text { 15-Day Running } \\
\text { Mean }\end{array}$ \\
\hline 1 & 13 & 13 & 0 & & & & \\
\hline 2 & 4 & 17 & 20 & & & & \\
\hline 3 & 3 & 20 & 9 & 22 & & & \\
\hline 4 & 2 & 22 & 5 & 35 & 92 & & \\
\hline 5 & 0 & 22 & 28 & 75 & 130 & 185 & \\
\hline 6 & 26 & 48 & 70 & 123 & 168 & 172 & \\
\hline 7 & 44 & 70 & 121 & 163 & 165 & 189 & 222 \\
\hline 8 & 51 & 121 & 137 & 163 & 184 & 186 & 222 \\
\hline 9 & 42 & 163 & 93 & 158 & 184 & 184 & 239 \\
\hline 10 & 0 & 163 & 63 & 114 & 158 & 197 & 261 \\
\hline
\end{tabular}


Naing et al., / British Journal of Arts and Humanities, 4(1), 01-14, 2022

\begin{tabular}{|l|c|c|c|c|c|c|c|}
11 & 21 & 184 & 21 & 63 & 127 & 174 & 272 \\
\hline 12 & 0 & 184 & 21 & 34 & 79 & 130 & 272 \\
\hline 13 & 0 & 184 & 13 & 37 & 37 & 113 & 261 \\
\hline 14 & 13 & 97 & 16 & 16 & 71 & 96 & 254 \\
\hline 15 & 3 & 200 & 16 & 50 & 75 & 109 & 207 \\
\hline 16 & 0 & 200 & 37 & 75 & 88 & 88 & 168 \\
\hline 17 & 34 & 234 & 34 & 75 & 88 & 103 & 186 \\
\hline 18 & 25 & 259 & 72 & 72 & 90 & 140 & 236 \\
\hline 19 & 13 & $\mathbf{2 7 2}$ & 38 & 87 & 124 & 131 & $\mathbf{4 1 8}$ \\
\hline 20 & 0 & 272 & 28 & 90 & 128 & 131 & $\mathbf{5 0 3}$ \\
\hline 21 & 15 & 287 & 52 & 69 & 97 & 149 & $\mathbf{4 9 0}$ \\
\hline 22 & 37 & $\mathbf{3 3 2}$ & 56 & 59 & 90 & 186 & 748 \\
\hline 23 & 4 & 336 & 44 & $\mathbf{7 7}$ & 148 & $\mathbf{3 4 8}$ & 929 \\
\hline 24 & 3 & 339 & 25 & 133 & $\mathbf{3 3 0}$ & $\mathbf{4 2 8}$ & 955 \\
\hline 25 & 18 & $\mathbf{3 5 7}$ & 92 & $\mathbf{2 7 8}$ & $\mathbf{3 6 3}$ & $\mathbf{5 0 7}$ & 924 \\
\hline 26 & 71 & 428 & $\mathbf{2 7 1}$ & $\mathbf{3 5 9}$ & $\mathbf{4 5 5}$ & $\mathbf{6 6 1}$ & 899 \\
\hline 27 & 182 & $\mathbf{6 1 0}$ & $\mathbf{3 3 8}$ & $\mathbf{4 4 8}$ & $\mathbf{6 2 0}$ & 805 & 886 \\
\hline 28 & 85 & $\mathbf{6 9 5}$ & $\mathbf{3 5 9}$ & $\mathbf{5 9 8}$ & 798 & 827 & 886 \\
\hline 29 & 92 & $\mathbf{7 8 7}$ & $\mathbf{3 4 6}$ & $\mathbf{7 0 9}$ & $\mathbf{8 0 6}$ & $\mathbf{8 2 7}$ & \\
\hline 30 & 169 & $\mathbf{9 5 6}$ & $\mathbf{4 4 2}$ & $\mathbf{5 5 3}$ & $\mathbf{7 3 8}$ & $\mathbf{8 0 9}$ & \\
\hline 31 & 181 & $\mathbf{1 1 3 7}$ & $\mathbf{3 7 6}$ & $\mathbf{4 7 1}$ & $\mathbf{5 5 6}$ & $\mathbf{7 3 8}$ & \\
\hline
\end{tabular}

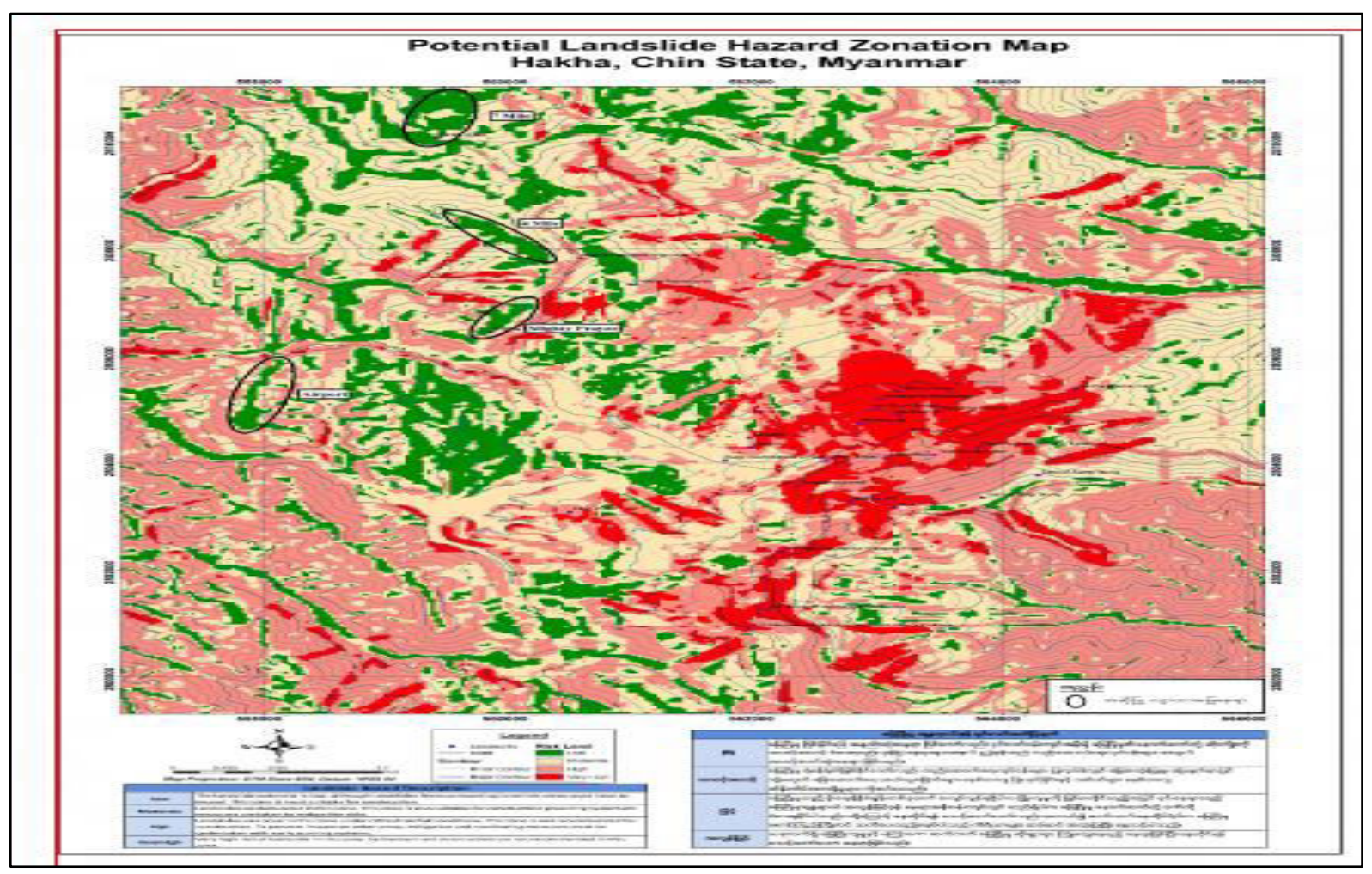

Fig. 11: Potential Landslide Hazard Zone in Hakha and it's Environ (Source: Myanmar Geoscience Society, 2015).

Table 5: Classification of Landslide Susceptibility and Rainfall Threshold in July 2015, Hakha Area (Source: Based on rainfall data in 2015).

\begin{tabular}{|c|c|c|c|c|c|}
\hline Zone & $\begin{array}{c}\text { Rainfall Warning } \\
(\mathbf{m m})\end{array}$ & $\begin{array}{c}\text { Rainfall Threshold } \\
(\mathbf{m m})\end{array}$ & Map Color & Landslide Susceptibility & $\begin{array}{c}\text { Elevation (Height) } \\
\text { mm }\end{array}$ \\
\hline 1 & 272 & 332 & Red & Very High & 1865 \\
\hline 2 & 333 & 358 & Pink & High & 1771 \\
\hline 3 & 359 & 428 & Red- pink & Moderate & 1649 \\
\hline 4 & 429 & 610 & Green & Low & 1582 \\
\hline
\end{tabular}

UniversePG I www.universepg.com 


\section{DISCUSSION:}

In Hakha there occurred three types of landslides: rotational slide, flow type, and translational slide or plane failure. Major causes appeared to be steepness of slopes, rising pore water pressure, run-off erosion, local geologic structure, presence of poor or unconsolidated soil, and continuous heavy rain during the successive days. The landslide that occurred in Rhung Taung is considered to be of rotational slide type and the triggering event took place under the continuous rain of $21^{\text {st }}-30^{\text {th }}$ July 2015. The landslide mentioned above was found related to the geological structure of the Hakha area which is formed of folds, joints, and local faults because the earth slid according to the dip orientation of the rocks. In the map of potential landslide zone, four hazard zones are described: very high hazard zone, high hazard zone, moderate hazard zone, and low hazard zone. Rhung Taung falls in the very high hazard zone colored in red and its area is not suitable for people and animals to live. The result shows that more than $332 \mathrm{~mm}$ of cumulative daily rainfall of successive days can cause a 75 percent probability of landslide occurrence. In addition, debris that falls from hill-slopes usually blocks gullies and form natural dams. During heavy rain, the debris weakens and brings about debris flow and mudflow. According to field observation, settlements from the damaged areas which fall in the Very High Hazard Zone are proposed to be relocated to Sutaung Hill near the Hakha-Falam Road, sites at 4 miles distance and at 7 miles distance, and those near the Airfield lying along the HakhaHtantalan Road. The High Hazard Zone colored in pink is where instruments for warning systems should be installed and monitored. If cumulative daily rainfall of successive days within one month reaches $358 \mathrm{~mm}$ (14.1 inch), it is estimated that the probability of landslide occurrence will be 90 percent. In the Moderate Hazard Zone colored in yellow, landslide sometimes occurs. If housing and construction workers want to be carried out, it needs to examine the relief condition and underground drainage pattern, to construct the retaining walls with the help of engineers, to grow grass systematically, and to grow plants that can protect soil from erosion (Wallace, 1895). If cumulative daily rainfall of successive days within one month reaches 428 $\mathrm{mm}$ (16.85 inches), it is estimated that the probability of landslide occurrence will be 90 percent. In the UniversePG I www.universepg.com
Moderate Hazard Zone although landslide sometimes occurs, if construction work wants to be done it needs to prepare and use the relief condition and underground drainage pattern, to build retaining walls systematically, and to grow chosen plants that can protect soil from erosion. The Low Hazard Zone or the green zone is the least susceptibility to landslide and so the zone is most suitable for settlements and construction work. In this zone, if cumulative daily rainfall of successive days within one month reaches $610 \mathrm{~mm}$ (17.40 inches), it is estimated that landslide is likely to occur. In addition, in this research it is described needs and preparation to be implemented in each zone, techniques for drain system, and slope-maintaining systems by growing plants for slope stability, and do-anddon'ts in potential landslide hazard area. The types of landslides that occurred in the Hakha area are found to be those of rotational slide, flow type, and translational slide or plane failure (Sekhar et al., 2008).

\section{CONCLUSION:}

Major causes are steepness of slopes, increasing pressure of pore water, erosion process, geologic structure, and the existence of debris and triggering events. In the map of potential landslide zone, four zones are described. Of these, the very high hazard zone and the high hazard zone are the ones in which people should not reside (Pravat Kumar et al., 2016). If people continue living there, landslide-monitoring and warning instruments should be installed. If people live near/in the very high hazard zone, it is better to move them away. In the moderate zone, although landslide sometime can occur, construction work can be done by preparing the ground surface, by using the systematic drainage pattern, by constructing the retaining walls and by growing grass and plants that can reduce slope erosion (Tiziano Tempesta, 2010). The best place for construction work is the low hazard zone where landslide is least likely to occur. Finally, I would like to suggest that Hakha area is still lack of further research that can support the development of its area (Tiziano, 2010).

\section{ACKNOWLEDGEMENTS:}

I wish to express my most grateful appreciation to $\mathrm{U}$ Paul Lum Mint Htan Minister of Social Affair, Ministry of Social Affairs in Chin State, for help during field observations in Chin State, Rector Dr. Thein 
Win and Dr. Nyo Nyo, Professor and Head, Dept. of Geography, Mandalay University for their kindness in permitting me to do this research. I would like to thank my teachers Dr. Win Maung, Retired Prof. of Department of Geography, University of Mandalay, for his critical reading and for correcting the errors. I wish to express my most grateful appreciation to my pupils, teachers, and students of the Geography Dept. Hakha Degree College for participating with me to do this research paper. I am also grateful to all my teachers, and staff of Departments of various offices for their help in field survey in Hakha Township.

\section{REFERENCES:}

1) Bagchi R, Miah MA, Hazra P, Hasan R, Mondal HS, and Paul SK. (2020). Exploring the effect of rainfall variability and water extent in tanguar haor, Sunamganj, Aust. J. Eng. Innov. Technol., 2(4), 66-76. https://doi.org/10.34104/ajeit.020.066076

2) Border \& Development Committee, (2018). Reports, Hakha Township, Myanmar.

3) Chris P. Potos, (1983). Assessment of Potential Groundwater Contamination in Indiana, Water Division, Water Supply Branch U.S., Environmental Protection Agency, P 230, India. https://nepis.epa.gov/Exe/ZyPDF.cgi/20014U0U.P DF?Dockey $=20014$ U0U.PDF

4) Geological Setting, (2011). Geochemistry and genesis of the Sepon gold and copper deposits, Laos.

https://1library.net/document/rz39k4dz-geologicalsetting-geochemistry-genesis-sepon-copper-deposit s-laos.html

5) Government of Chin State, (2018). Chin State Human Development Report, Department of Planning \& Coordination, New Concept Information System Pvt. Ltd., New Delhi.

6) Gregory. S., (1978). Statistical Methods and the geographer, Fourth Edition, London \& New York.

7) Jessica L.M. Gutknecht, (2016).Microbial response over time to hydrologic and fertilization treatments in a simulated wet prairie, Plant and Soil , 284(1),85-100, https://doi.org/10.1007/s11104-006-0032-1
8) Jun Yang et al. (2018). How to Measure Urban Land Use Intensity? MDPI Publication, China.

9) Justin R., (2009). Spatial patterns of Rainfall and shallow landslide, University of Washington, USA.

10) Kate Mickelson, (1984). Landslide, Landslide Hazard Program Team Lead, 360-902-1488. https://www.dnr.wa.gov/programs-and-services/ge ology/geologic-hazards/landslides

11) Lee M. J, (2014). Landslide hazard mapping considering rainfall probability in Inje, Korea, University of Science and Technology, Korea.

12) Meteorology \& Hydrology, (2015). Departmental Report of Mandalay Region, Myanmar.

13) M. J. Lee, I. Park, J. S. Won \& S. Lee, (2014). Landslide hazard mapping considering rainfall probability in Inje, Korea. Page 424-446. https://www.tandfonline.com/10.1080/\%20194757 $\underline{05.2014 .931307}$

14) M.J. Lee, I. Park, J.S. Won \& S. Lee, (2016). Landslide hazard mapping considering rainfall probability In Inje, Geomatics, Natural Hazards and Risk, 7(1), 424-446, https://doi.org/10.1080/19475705.2014.931307

15) Myanmar Geoscience Society, (2015). Report of Chin State, Myanmar.

16) Mihai Ciprian Margarint, (2013). Landslide Susceptibility Assessment: GIS Application to a Complex Mountainous Environment: The Carpathians: Integrating Nature and Society towards Sustainability, Pages 14, and Springer.

17) Nader Sadatkhah, Azman Kassim \& Lee Min Lee, (2015). Hulu Kelang, Malaysia regional mapping of rainfall-induced landslides using TRIGRS model, Arabian J. of Geosciences, 8, pp. 3183-3194.

18) Pravat Kumar Shit, Gouri Sankar Bhunia \& Ramkishna Maiti, (2016). Modeling Earth System and Environment: Potential Landslide Susceptibility mapping Using Weighted Overlay Model (WOM),

https://link.springer.com/article/10.1007/s40808-01 6-0078-x

19) Sekhar L. Kuriakose \& G Sankar \& C. Muraleed Haran, (2008). Environmental Geology: History of landslide susceptibility and a chorology of landslide-prone areas, 57(7), 1553-1568, https://doi.org/10.1007/s00254-008-1431-9 
20) Western Ghats of Kerala, India. https://www.researchgate.net/publication/2256847 $\underline{05}$

21) Surabhi Kuthari, (2007). Establishing Precipitation Thresholds for Landslide Initiation along with Slope Characterization Using GIS-based Moedling, IIRS and ITC publication, India.

22) Togaru Surya Taeja et al. (2019). Determination of Rainfall Thresholds for Landslide Prediction Using An Algorithm-Based Approach: Case Study in the Darjeeling Himalayas, India.
23) Tiziano Tempesta, (2010). The perception of agrarian historical landscapes: A study of the Venet plain in Italy, Landscape and Urban Planning, 97(4), 258-272, https://doi.org/10.1016/j.landurbplan.2010.06.010

24) Wallace, A. R., (1895). Natural selection and tropical nature: Essays on descriptive and theorical biology. $2^{\text {nd }}$ ed. London: Macmillan. http://test.darwin-online.org.uk/converted/Ancillar y/1895_NaturalSelection_A238.html

\section{APPENDIX:}
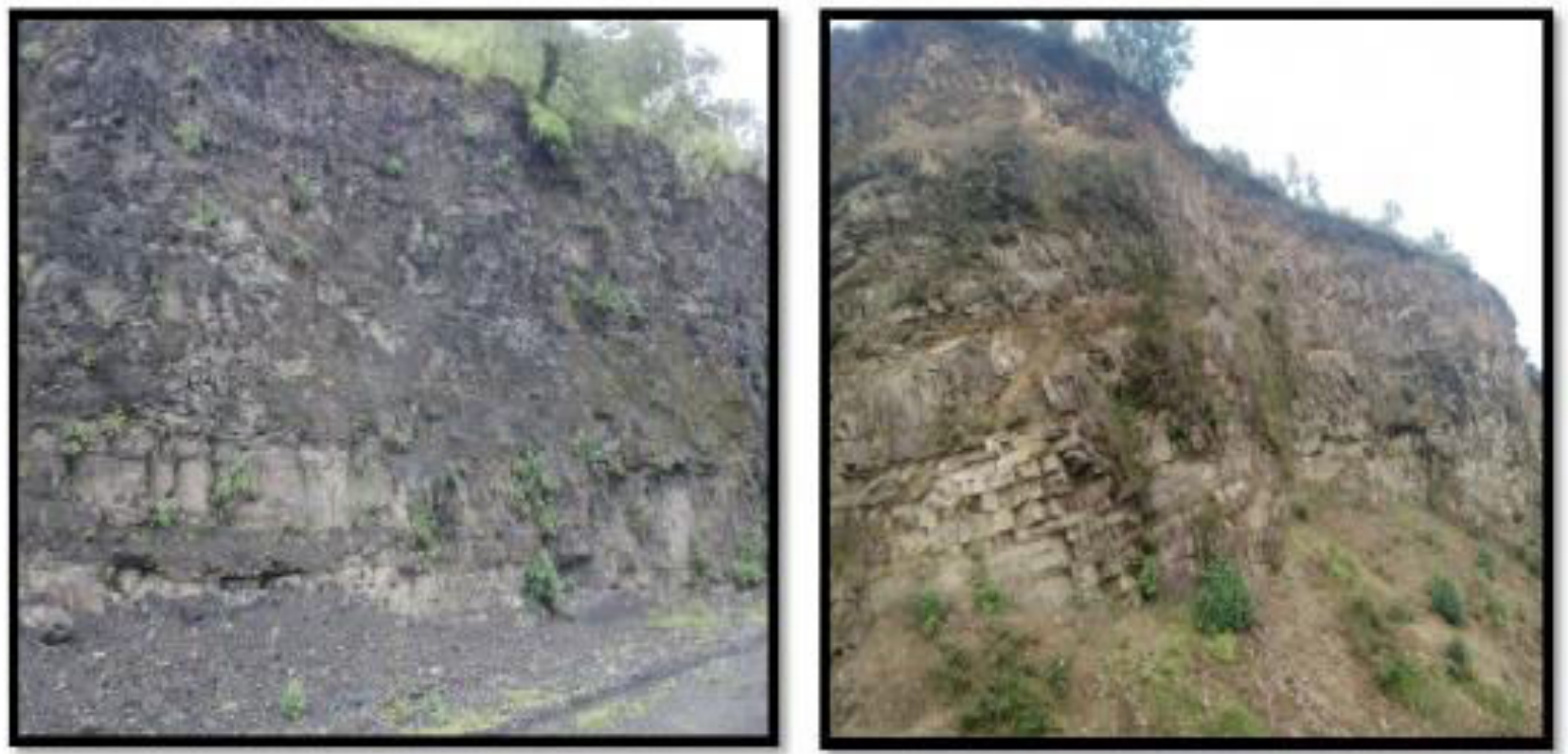

Photo 1: Thin to Medium bedded Sandstone at Rhung Taung Long 933656 E and Lat 2238 25, UTM 2293.10.
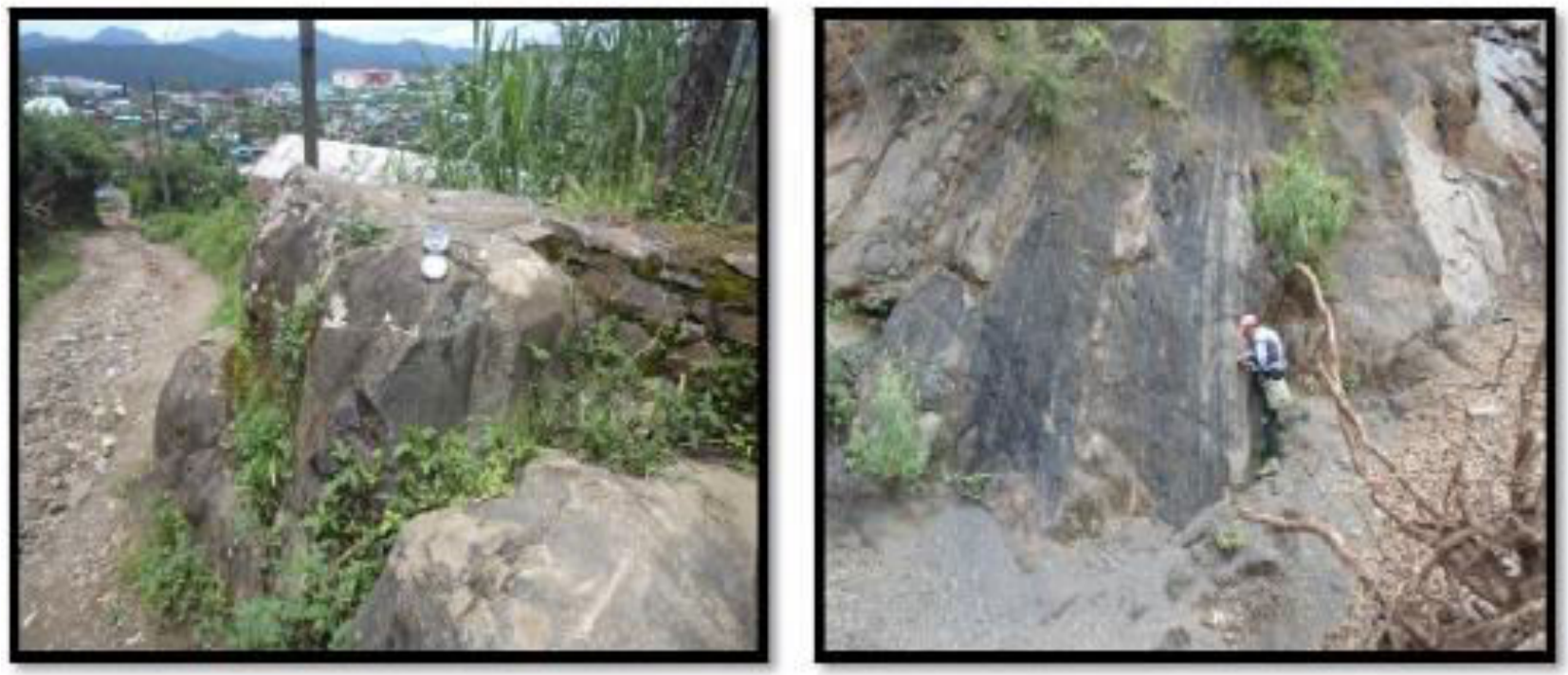

Photo 2: Light Grey Colour Limestone near Ring Road of Hakha Town. 


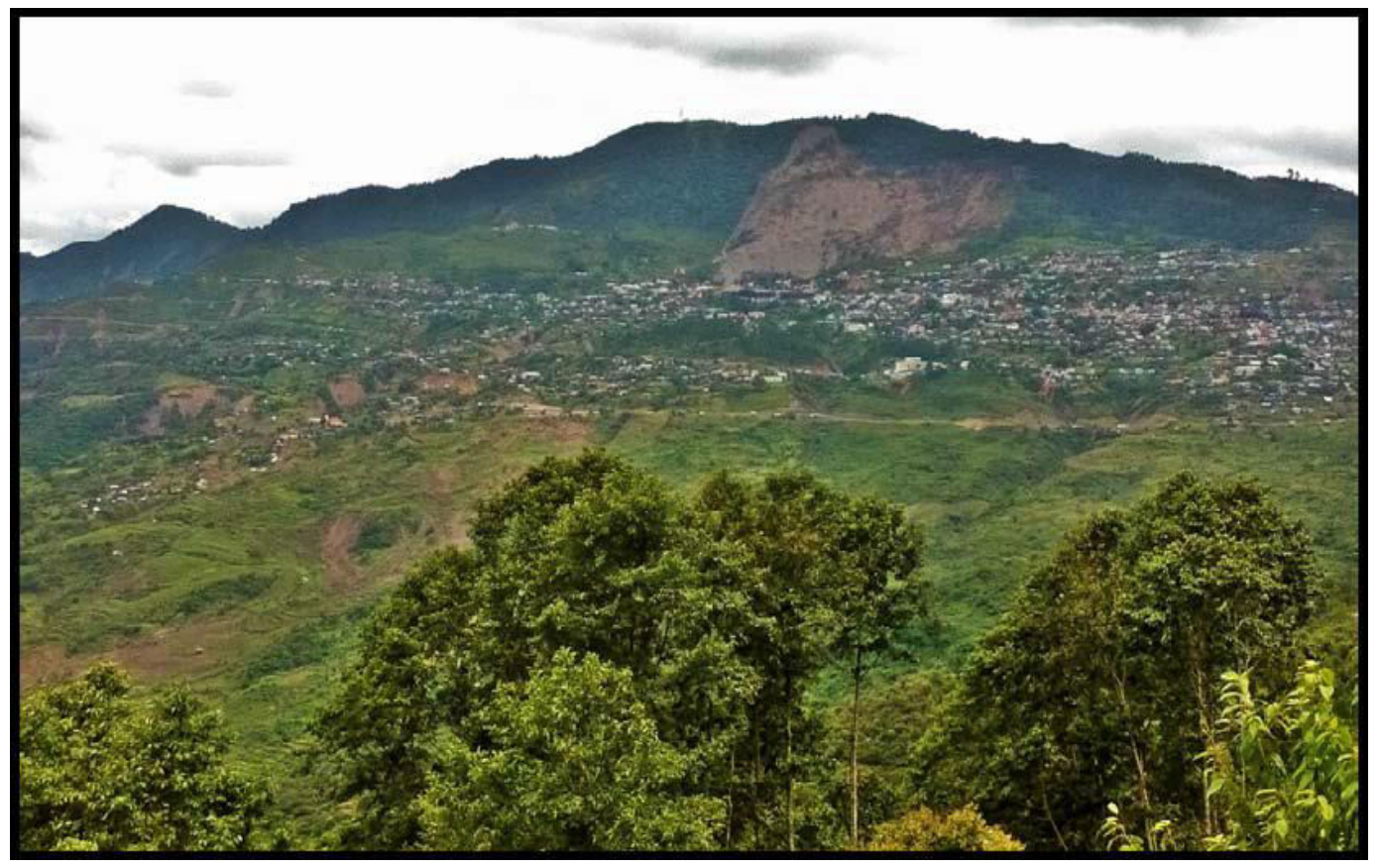

Photo 3: Landslide Effects at Rhung Taung in Hakha Area.

Citation: Naing MT, Aye MM, and Oo KL. (2022). Rainfall and landslide susceptibility in Hakha environ in northern Chin state, Myanmar, Br. J. Arts Humanit., 4(1), 01-14. https://doi.org/10.34104/bjah.02201014 @ @ 